\title{
A METHOD FOR DEPROTEINIZATION OF BLOOD AND OTHER BODY FLUIDS
}

\author{
BY \\ G. HUNTER \\ From Cowley Road Hospital, Oxford
}

(RECEIVED FOR PUBliCATION APRIL 26, 1956)

Deproteinization is a necessary step in many procedures for the chemical analysis of body fluids. A variety of reagents have been used for this purpose, especially in blood analysis. Of these perhaps tungstic acid and trichloracetic acid are the most widely used to-day, and for this reason we may consider them a moment. Folin and Wu (1919) introduced tungstic acid to prepare proteinfree filtrates for their system of blood analysis. In this method it is usual to employ $667 \mathrm{~m} . \mathrm{Eq}$. of the acid to precipitate the proteins from a litre of plasma or whole blood and twice this concentration to deproteinize the same volume of packed erythrocytes. With the use of sodium tungstate and sulphuric acid equivalent amounts of $\mathrm{Na}$ and $\mathrm{SO}_{4}$ are of course added to the filtrate. Trichloroacetic acid is commonly used in a $5 \%(\mathrm{w} / \mathrm{v})$ concentration in the filtrate, and it must be used in not less than half of this concentration. If the blood is diluted 1 in 10 this means that the acid used equals $4 \mathrm{~m}$. Eq./litre blood and the filtrate is more than $3.0 \mathrm{~N}$ acid.

For such reasons tungstic and trichloroacetic acids are unsuitable deproteinizing agents in many analytical methods, in procedures for the isolation of solutions for chromatography, and other modern techniques. It therefore seems desirable to have other means of deproteinization that will avoid the addition of gross amounts of extraneous matter to the filtrates, that can be rapidly applied, yield filtrates near neutrality, and cause a minimum distortion of the chemical picture of the fluids concerned. The present communication is an attempt in this direction. A method is described for the preparation of protein-free filtrates of blood, which is also applicable to other body fluids. It depends on the adjustment of the $p \mathrm{H}$ of the diluted fluid in question to a value suitable for the precipitation by heat of the proteins present. Plasma, cells, and whole blood require about 50,27 , and $40 \mathrm{~m}$.Eq. acetic acid/1. respectively for $p \mathbf{H}$ adjustment. The filtrates obtained after heating briefly at $100^{\circ} \mathrm{C}$. are clear and colourless and remain clear on addition of sulphosalicylic acid.

\section{Deproteinization of Blood}

pH Adjustment.-For this purpose $0.05 \mathrm{~N}$-acetic acid is used routinely, but other acids may be used (see p. 163). One volume of plasma, cells, and whole blood requires $1.0,0.54$, and 0.80 volume respectively of the acetic acid. Water is added to suitable dilution, e.g., 1 in 5 to 1 in 50, and the contents are mixed.

Protein Precipitation.-When the volume of the mixed solution is less than $10 \mathrm{ml}$. it is convenient to have it in a centrifuge tube. This is immersed for three to five minutes in boiling water, then cooled, spun, and the supernatant fluid is transferred to a clean tube.

With larger volumes of course the time of heating must be extended so that the fluid is at $100^{\circ} \mathrm{C}$. for two to four minutes.

\section{Deproteinization of Other Fluids}

Cerebrospinal fluid (C.S.F.) protein is satisfactorily precipitated with 0.7 volume of the acid at 1 in 10 dilution. In our experience protein is more easily removed from C.S.F. by this method than by either tungstic or trichloroacetic acid.

Oedema fluids, nasal discharges, etc., have been found to require 0.4 to 0.7 volume of the acid, the amount depending largely on the amount of $\mathrm{NaHCO}_{3}$ and protein present. When the coagulation is not complete the solution should be adjusted to $p \mathrm{H} 5.3$, at which point we have not failed to get good coagulation. When means are not available for $p \mathrm{H}$ determination a final adjustment with a drop or two of 1.0 M-acetic acid-sodium acetate buffer $p \mathrm{H} \quad 5.3$ is usually effective.

\section{Deproteinization of Urine}

The composition and $p \mathrm{H}$ of urine are so variable that no rule can be followed. Our practice is to adjust the $p \mathrm{H}$ of a given volume of urine with a measured amount of $1.0 \mathrm{~N}$-acetic acid to 5.2 to 5.3 , using a $p \mathrm{H}$ meter and glass electrode, then diluting as analytical requirements indicate before heating to precipitate the protein. 


\section{Methods}

Non-protein nitrogen was determined on the blood filtrates shown in Table $\mathrm{I}$ by digestion with $\mathrm{H}_{2} \mathrm{SO}_{4}$, addition of $\mathrm{K}_{2} \mathrm{~S}_{2} \mathrm{O}_{8}$ to clear, followed by heating for 30 min., with subsequent nesslerization.

Acid required for the $p \mathrm{H}$ shift of Tables II and III was determined by titrating $1 \mathrm{ml}$. plasma, diluted with $9 \mathrm{ml}$. water, with $0.05 \mathrm{~N}$-acetic acid to $p \mathrm{H} 5.3$ with the glass electrode; and $1 \mathrm{ml}$. cells, diluted with $19 \mathrm{ml}$. water, to $p \mathrm{H} 7.0$ with the same acid.

TABLE I

NON-PROTEIN NITROGEN OF BLOOD DETERMINED ON CORRESPONDING FILTRATES OBTAINED WITH TUNGCORRESPONDING FILTRATES OBTAINED WITH
STIC ACID AND THE ACID-HEAT METHOD

\begin{tabular}{c|c|c|c|c|c|c}
\hline \multirow{2}{*}{$\begin{array}{c}\text { Blood } \\
\text { No. }\end{array}$} & \multicolumn{3}{|c|}{ Tungstic Acid } & \multicolumn{3}{c}{ Acid-heat } \\
\cline { 2 - 7 } \cline { 4 - 6 } & Plasma & Cells & Blood & Plasma & Cells & Blood \\
\hline 1 & 34 & 55 & 45 & 46 & 70 & 59 \\
2 & 25 & 51 & 38 & 30 & 60 & 42 \\
3 & 36 & 80 & 60 & 41 & 88 & 71 \\
4 & 19 & 35 & 26 & 35 & 45 & 50 \\
5 & 32 & 44 & 42 & 55 & 74 & 64 \\
\hline
\end{tabular}

Results are expressed in $\mathrm{mg} . / 100 \mathrm{ml}$.

TABLE II

ESTIMATE OF ACID* REQUIRED TO SHIFT $p H$ of 1 LITRE PLASMA TO $5 \cdot 3$

Protein, $70 \times 0.243$ (Peters and van Slyke, 1931) $=17 \mathrm{~m} . \mathrm{Eq}$

$\mathrm{NaHCO}_{3}$, at $p \mathrm{H} \mathrm{5.3} \mathrm{(4} \mathrm{m.Eq.} \mathrm{as} \mathrm{NaHCO}_{3}$ )

Total by estimate

Found in practice $=41$ "

* It is assumed that plasma contains $70 \mathrm{~g}$. protein and $28 \mathrm{~m}$.Eq. $\mathrm{NaHCO}, 40 \mathrm{~m}$.Eq. strong acid is equal to about $50 \mathrm{~m}$.Eq. acetic acid at $p \mathrm{H} \quad 5 \cdot 3$.

TABLE III

ESTIMATE OF ACID REOUIRED TO SHIFT $p H$ OF 1 LITRE LAKED CELLS FROM 7.5 TO 7.0 *

About $2.5 \mathrm{~m}$.Eq. acid required to shift $17 \mathrm{~g}$. $\mathrm{Hb}$ through $1 \mathrm{pH}$ unit

$$
\begin{aligned}
& \text { (Peters and van Slyke, 1931). Hence acid required here is } \\
& \frac{320}{17} \times 2.5 \times 0.5=23.5 \mathrm{~m} . \text { Eq } \\
& \text { To shift } 16 \text { m.Eq. } \mathrm{NaHCO}_{3} \text { from } p \mathrm{H} 7.5 \text { to } p \mathrm{H} 7.0 \\
& \text { requires } \\
& \text { Total by estimate } \\
& \text { Found in practice } \\
& =1.2, \\
& =24 \cdot 7 \text {, }
\end{aligned}
$$

* It is assumed that cells contain $320 \mathrm{~g}$. haemoglobin and $16 \mathrm{m.Eq}$ $\mathrm{NaHCO}_{3}$

\section{Results}

The filtrates obtained are clear and colourless and remain clear on addition of sulphosalicylic acid. This is conclusive evidence that there is less than about $2 \mathrm{mg}$. protein $/ 100 \mathrm{ml}$. filtrate. The xanthroproteic and biuret tests are faintly positive in the filtrates as they are also in corresponding tungstic acid filtrates and do not necessarily signify the presence of protein. For practical purposes the filtrates are therefore free from protein.

Though free from protein, the non-protein nitrogen (N.P.N.) content of the filtrates from plasma, cells, and whole blood is uniformly higher than the N.P.N. values obtained on corresponding tungstic acid filtrates, as shown in Table I.
The $p \mathrm{H}$ of the filtrates is somewhat higher, 0.1 to $0.2 \mathrm{pH}$ unit, than that of the solutions before heating, due to loss of $\mathrm{CO}_{2}$.

Jaundiced sera yield colourless filtrates indicating that, of the pigments, at least bilirubin is adsorbed on the protein precipitate.

\section{Discussion}

This method of deproteinization has proved practicable for the determination of ergothioneine in blood (Hunter, 1949), polyvinyl pyrrolidone (plasmosan) in blood serum (Campbell and Hunter, 1953), and for the estimation of isonicotinic acid hydrazide in blood serum (Hunter, 1955). It has now been found that filtrates from blood and other body fluids prepared in this way are suitable for the determination of $\mathrm{Mg}$ and Ca (Hunter, 1956).

The "heat and acetic acid test" has of course long been used as a qualitative clinical test for protein in urine, but it is usually performed rather haphazardly, without control of $p \mathrm{H}$, and to differentiate protein from precipitated phosphates.

The method has not been suggested as a general and quantitative means for deproteinizing blood and other body fluids, though there are a few observations in the literature on the controlled use of acetic acid, e.g., by Rimington (1940) to prepare filtrates of plasma containing mucoprotein, by Solomon, Johnson, Sheffner, and Bergeim (1951) to prepare tissue filtrates for chromatography, and by Ramsay (1953), who used an acetic buffer at $p \mathrm{H} 5.0$ to remove protein in the course of the determination of $\mathrm{Fe}$ in plasma and serum. As far as I am aware there has been no study of this method of deproteinization.

The arbitrary finding that plasma requires the addition of almost twice as much acid as an equal volume of packed cells was at first surprising in view of the much greater concentration of protein and base in the cells. It was observed, however, that the protein-free filtrates from plasma or serum had a $p \mathbf{H}$ about 5.3, and the protein-free filtrates from packed cells had a $p H$ about 7.0 at room temperature, $p \mathrm{Hs}$ not far removed from the isoelectric points of denatured serum albumin and globulin and the isoelectric point of haemoglobin respectively. Postulating a normal plasma as containing 70 g. protein and $28 \mathrm{~m} . \mathrm{Eq}$. $\mathrm{NaHCO}_{3}$, the amount of strong acid necessary to shift its $p \mathrm{H}$ to 5.3 is calculable with fair accuracy, according to Table II, and agrees in a satisfactory manner with the amount found in practice. The $\mathrm{NaHCO}_{3}$ present in plasma accounts for more than half the acid required. 
As might be expected the $p \mathrm{H}$ value of the acid used has some effect on the amount required in different $p \mathrm{H}$ regions. For example, there is little difference in the range $p \mathbf{H}$ 7.5-7.0, whether hydrochloric or acetic acid is used, but when the $p \mathrm{H}$ has to be shifted to about 5.3, more of the weak acid is required. The following amounts (in $\mathrm{ml}$.) of different acids were required to shift $1 \mathrm{ml}$. of

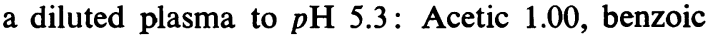
0.88 , lactic 0.80 , perchloric, trichloroacetic and hydrochloric 0.75 , tartaric 0.85 , sulphuric 0.80 , and citric 1.05. Similar values are obtained on titration of bicarbonate solutions. On heating the plasma solutions clear filtrates were obtained. It should be noted, however, that there is a marked rise in the $p \mathrm{H}$ of trichloroacetic acid filtrates owing to the decomposition of the acid on heating.

In the case of cells the situation is quite different, as seen from Table III. The effect of $\mathrm{NaHCO}_{3}$ is almost negligible over the relevant $p \mathrm{H}$ range, but to shift the haemoglobin over $0.5 \mathrm{pH}$ takes more acid than that required to shift the plasma protein over $2.0 \mathrm{pH}$. Again the acid calculated as required is near that found in practice, especially when a small amount of plasma with the cells is accounted for.

What remains surprising is that the proteins in whole blood are effectively precipitated at about $p H$ 6.4. When a 1 in 10 dilution of plasma is heated at this $p \mathrm{H}$ it will not coagulate well; the supernatant will be opaque or very milky in appearance. Likewise solutions of cells heated at $p$ H 6.4 give dirty red suspensions. Yet when both cells and plasma are present in about equal volume the supernatant is clear and colourless. At $p \mathrm{H}$ 6.4 the plasma proteins will be charged negatively and the haemoglobin positively, and it is suggested on those grounds that coprecipitation is a major factor in the coagulation of the denatured protein from solutions of whole blood.

Range of $p H$ Tolerance for Deproteinization.It may be observed that $p \mathrm{H} 5.3$ has been chosen in Table II to calculate the buffering capacity of plasma. This point was chosen as a mean of a range $p H$ 5.7-5.0, in which crystal clear filtrates of plasma are usually obtained. This range is of considerable importance, as the present method would not otherwise be practicable for different bloods. Expressed in another way, it is found that $1 \mathrm{ml}$. diluted normal plasma requires $1.0 \mathrm{ml}$. $0.05 \mathrm{~N}$-acetic acid for adjustment to the $p \mathrm{H}$ suitable for deproteinization by heat. Were $0.9 \mathrm{ml}$. acid added, the $p \mathrm{H}$ in such a diluted plasma would be near 5.7 , and were $1.1 \mathrm{ml}$. acid added the $p H$ would be near 5.0. We thus have a range of toler- ance of $\pm 10 \%$ of the amount of acid recommended for use. This covers all but quite exceptional plasmas-more than a $20 \%$ change in plasma protein or more than a $15 \%$ change in plasma bicarbonate.

Like arguments apply to the deproteinization of cells and whole blood.

It may be noted that the loss of $\mathrm{CO}_{2}$ from blood has no influence on the amount of acid required for $p \mathrm{H}$ adjustment of the whole blood, as it is a volatile acid. However, plasma separated from blood with a low $\mathrm{CO}_{2}$ tension will have more chloride present and thus require less acid for $p \mathrm{H}$ adjustment, and vice versa for plasma separated from blood with a high $\mathrm{CO}_{2}$ tension. Only under extreme conditions does this chloride shift exceed the range stated above.

Despite the range of tolerance recognized here it should be emphasized that the amounts of acid used must be measured precisely.

The general directions are only applicable to fresh bloods. On long standing, acid will frequently develop in blood.

Fluids Other Than Blood.-The principles discussed above for the precipitation of the proteins from blood plasma would appear to apply to body fluids in general. In the case of C.S.F. the protein is normally a negligible factor as a buffer, but the total $\mathrm{CO}_{2}$ is somewhat higher than that of plasma. Hence we might expect that unit volume will require about 0.7 volume of $0.05 \mathrm{~N}$-acetic acid. Cerebrospinal fluid also serves to show the sensitivity of the process. For example, $1 \mathrm{ml}$. of a C.S.F. containing $22 \mathrm{mg}$. protein $/ 100 \mathrm{ml}$., with $8.3 \mathrm{ml}$. water and $0.7 \mathrm{ml}$. acetic acid, showed a well-coagulated precipitate after heating.

When the acid requirement of the fluid is unknown and its volume perhaps small, or $p \mathrm{H}$ determinations are not readily made, it is suggested that 0.6 volume of acid be tried, and if this fails to give a good coagulation a drop or two of acetate buffer at $p \mathrm{H} 5.3$ may be used. As noted above, Ramsay has suggested the use of a similar buffer

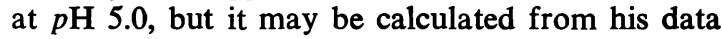
that he is adding some 25 times more acetate than used in the present method.

In a case of nephrosis studied with Dr. L. C. A. Nunn of the Pathology Laboratory, Stoke Mandeville Hospital, Aylesbury, the present method was found useful in the precipitation of urinary protein without the precipitation of polyvinyl pyrrolidone (" plasmosan ") which had been administered to the patient to maintain oncotic pressure. It was thus possible to determine both the protein and plasmosan excreted in the urine. 
Non-protein Nitrogen.-The non-protein nitrogen values of the filtrates obtained by the present method present a point of some interest. Its elucidation awaits further investigation. However, it was stated by Benedict and Newton (1929) that tungstic acid precipitates ergothioneine in blood, and from similar findings the present method of deproteinizing (Hunter, 1949) was developed. It would appear that non-protein substances other than ergothioneine are involved, and it would no doubt be of some interest to find out what they are.

It appears unlikely that any proteolysis occurs,

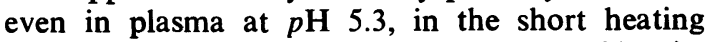
time. Extension of the heating time to $30 \mathrm{~min}$. was found to have no effect on the non-protein nitrogen.

\section{Summary}

A method is described for the deproteinization of blood and other body fluids, at the usual dilutions of 1 in 5 to 1 in 50, which depends on the addition of small amounts of acid followed by a brief period of heat at $100^{\circ} \mathrm{C}$.

The requisite amount of acid is calculable from the buffer capacity, due mainly to $\mathrm{NaHCO}_{3}$ and protein, and the $p \mathrm{H}$ shift involved.
The filtrates obtained are clear and colourless and show no clouding on the addition of sulphosalicylic acid, but they contain more non-protein nitrogen than corresponding filtrates obtained with tungstic acid.

Some of the factors in the deproteinization process are discussed and the advantages of such filtrates for analytical and other purposes are indicated.

I am indebted to Miss M. Massey Stewart for assistance. The work is part of a programme in the development of methods for the study of the bloodcerebrospinal-fluid barrier in association with Dr. H. V. Smith, Reader in Medicine, Radcliffe Infirmary.

\section{REFERENCES}

Benedict, S. R., and Newton, E. B. (1929). J. biol. Chem., 82, 5.

Campbell, H., and Hunter, G. (1953). Lancet, 1, 197.

Folin, O., and Wu, H. (1919). J. biol. Chem., 38, 81 .

Hunter, G. (1949). Canad. J. Res. (E), 27, 230.

- (1955). Brit. med. J., 1, 585.

- (1956). Biochem. J., 62, 28P, 29P.

Peters, J. P., and van Slyke, D. D. (1931). Quantitative Clinical Chemistry, Vol. 1, pp. 539 and 661. Williams and Wilkins, Baltimore.

Ramsay, W. N. M. (1953). Biochem. J., 53, 227.

Rimington, C. (1940). Ibid., 34, 931.

Solomon, J. D., Johnson, C. A., Sheffner, A. L., and Bergeim, O (1951). J. biol. Chem., 189, 629. 